Jurnal Pemberdayaan: Publikasi Hasil Pengabdian kepada Masyarakat

Vol. 4, No. 3, Desember 2020, Hal. 311-318

ISSN: 2580-2569; e-ISSN: 2656-0542

DOI: https://doi.org/10.12928/jp.v4i3.2263

\title{
Pelatihan Pembelajaran Daring sebagai Langkah Persiapan Guru SMK Dalam Melaksanakan Learning From Home di Masa Pandemi Covid-19
}

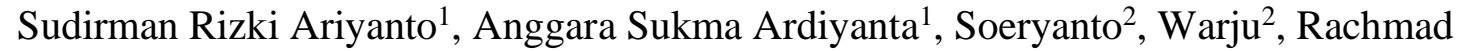 \\ Syarifudin Hidayatullah ${ }^{2}$, Yelma Dianastiti ${ }^{1}$
}

Universitas Bhinneka PGRI Tulungagung, Fakultas Sains dan Teknologi, Program Studi Pendidikan

Vokasional Teknologi Otomotif, Jl. Mayor Sujadi No.7, Kedungwaru, Kabupaten Tulungagung ${ }^{1}$

Universitas Negeri Surabaya, Fakultas Teknik, Jurusan Teknik Mesin, Jl. Ketintang, Gayungan, Kota Surabaya ${ }^{2}$

Email: sudirman@ @stkippgritulungagung.ac.id

\begin{abstract}
ABSTRAK
Pandemi Covid-19 telah merubah pola belajar siswa di seluruh dunia yang sebelumnya dilakukan secara tatap muka dan sekarang telah beralih menuju pembelajaran daring. Namun yang menjadi permasalahan adalah tidak semua sekolah siap untuk melaksanakan pembelajaran daring dalam waktu yang cukup lama. Kegiatan pengabdian kepada masyarakat (PKM) ini bertujuan untuk melatih para peserta dalam: (1) menggunakan platform google classroom; (2) menggunakan platform zoom cloud meetings; dan (3) menggunakan web tool quizizz. Kegiatan PKM ini dilakukan menggunakan metode pelatihan dan pendampingan. Subjek kegiatan atau perserta pelatihan berjumlah 50 orang guru. Waktu kegiatan dilaksanakan selama dua hari yakin tanggal 20 hingga 21 Maret 2020 yang diselenggarakan di SMK Dharma Bahari Surabaya. Hasil dari kegiatan PKM ini adalah secara berurutan dari 50 orang guru sebanyak 34\%, 50\%, dan 8\% peserta masuk kategori "sangat baik", "baik" dan "cukup" dalam mengoperasikan google classroom, sedangkan 8\% lainnya masuk dalam kategori "kurang". Selanjutnya, secara berurutan sebanyak 40\%, 52\%, dan 2\% peserta masuk kategori "sangat baik", "baik" dan "cukup" dalam mengoperasikan zoom cloud meetings, sedangkan 6\% lainnya masuk dalam kategori "kurang". Kemudian, secara berurutan sebanyak 30\%, 56\%, dan 10\% peserta masuk kategori "sangat baik", "baik" dan "cukup" dalam mengoperasikan web tool quizizz, sedangkan 4\% lainnya masuk dalam kategori "kurang".
\end{abstract}

Kata kunci: Pandemi Covid-19, pembelajaran daring, google classroom, zoom cloud meetings, web tool quizizz

\begin{abstract}
The Covid-19 pandemic has changed the pattern of student learning throughout the world, which was previously done face-to-face and has now shifted to online learning. But the problem is that not all schools are ready to carry out online learning in quite a long time. This community service (PKM) activity aims to train participants in: (1) using the google classroom platform; (2) using the zoom cloud meeting platform; and (3) using the quizizz web tool. PKM activities are carried out using training and mentoring methods. The subject of training activities or participants totaling 50 teachers. When the activity is carried out for two days sure from March 20 to 21, 2020 held at the Dharma Bahari Vocational School Surabaya. The results of the PKM activities were that sequentially out of 50 teachers $34 \%, 50 \%$, and $8 \%$ of participants were in the "very good", "good" and "enough" categories in operating the google classroom, while the other 8\% were in the "less". Furthermore, 40\%, 52\%, and 2\% of participants, respectively, were categorized as "very good", "good" and "enough" in operating the zoom cloud meetings, while the other 6\% were in the "less" category. Then, in the order of 30\%, 56\%, and 10\% of participants entered the category of "very good", "good" and "enough" in operating web tool quizizz, while the other 4\% were in the "less" category
\end{abstract}

Keywords: Pandemic Covid-19, online learning, google classroom, zoom cloud meetings, web tool quizizz. 


\section{PENDAHULUAN}

Saat ini, pandemi corona viruses disease atau Covid-19 telah menghasilkan 5,323,657 kasus diseluruh dunia dengan angka kematian mencapai 340,324 orang dan 2,171,626 sedang dalam tahap penyembuhan (Worldometer, 2020). Tak terkecuali di Indonesia, virus ini menjadi sangat berbahaya dan telah merubah drastis cara hidup masyarakat dalam melakukan aktivitas sehari-hari. Sebagian masyarakat yang terbiasa bekerja di luar rumah dipaksa untuk melakukan work from home (WFH) (Dewayani, 2020). Sedangkan, sebagian masyarakat lain yang tidak dapat melakukan WFH diwajibkan untuk mentaati protokol WHO secara ketat seperti melakukan cuci tangan dengan benar, menggunakan masker, dan menerapkan physical distancing agar dapat beraktivitas di luar rumah dengan aman (Pratama, 2020).

Tidak cukup itu saja, beberapa sektor yang berkaitan dengan pengumpulan massa dalam jumlah besar mulai memberlakukan sejumlah pembatasan bahkan memberhentikan kegiatan untuk sementara waktu. Salah satu sektor yang paling banyak mengumpulkan massa adalah sektor pendidikan. Mengetahui besarnya potensi penularan Covid-19 pada sektor tersebut, pemerintah pusat dalam hal ini melalui Kementerian Pendidikan dan Kebudayaan mengeluarkan Surat Edaran Mendikbud Nomor 36962/MPK.A/HK/2020 tentang pembelajaran secara daring dan bekerja dari rumah dalam rangka pencegahan penyebaran corona virus disease (COVID- 19). Mendukung edaran tersebut, Gubernur Jawa Timur juga mengeluarkan Surat Edaran Nomor 420/1780/101.1/2020 tentang peningkatan kewaspadaan terhadap Covid-19 di wilayah Jawa Timur. Melalui kedua surat edaran tersebut dijelaskan bahwa bagi sekolah yang berada dibawah naungannya untuk segera melakukan persiapan secara matang untuk pelaksanaan pembelajaran daring selama masa pandemi Covid-19.

Merespon dari kedua edaran tersebut, SMK Dharma Bahari selaku salah satu sekolah menengah kejuruan swasta di Surabaya juga mulai melakukan beberapa persiapan guna menerapkan pembelajaran daring. Salah satu persiapan yang wajib untuk dilakukan adalah dengan memberikan pelatihan pembelajaran daring. Berdasarkan hasil wawancara dengan $\mathrm{Bu}$ Yuliatin selaku Wakil Kepala Sekolah bidang Sumber Daya Manusia (SDM) pada tanggal 14 Maret 2020 dijelaskan bahwa pelatihan ini sangat penting untuk dilakukan mengingat sebagian besar guru belum paham dan familiar dengan makna dan inti dari pembelajaran daring. Selain itu, belum menjadi suatu kebutuhan yang mendesak juga menjadi salah satu alasan mengapa hingga saat ini belum banyak guru yang pernah atau setidaknya mencoba menerapkan pembelajaran daring pada kelas yang mereka ajarkan (Basilaia \& Kvavadze, 2020).

Jika permasalahan tersebut tidak segera di atasi, maka tentunya pelaksanaan pembelajaran daring sebagaimana yang diinstruksikan oleh pemerintah pusat dan provinsi tidak akan berjalan secara maksimal. Dengan demikian, pelatihan pembelajaran daring sangat perlu untuk dilakukan melalui kegiatan pengabdian ini. Program yang akan dilaksanakan diantaranya (1) pelatihan penggunaan platform google classroom; (2) pelatihan penggunaan platform zoom cloud meetings; dan (3) pelatihan penggunaan web tool quizizz. Adapun tujuan dari kegiatan Pengabdian Kepada Masyarakat (PKM) ini adalah untuk meningkatkan pengetahuan dan keterampilan guru SMK Dharma Bahari Surabaya dalam melaksanakan pembelajaran daring yang efektif, efisien, dan menyenangkan.

\section{METODE}

Kegiatan PKM ini dilakukan dengan metode pelatihan dan pendampingan. Subjek kegiatan atau perserta pelatihan berjumlah 50 orang guru dari SMK Dharma Bahari Surabaya. Program PKM meliputi (1) pelatihan penggunaan platform google classroom; (2) pelatihan penggunaan platform zoom cloud meetings; dan (3) pelatihan penggunaan web tool quizizz. Waktu kegiatan dilaksanakan selama dua hari yakin tanggal 20 hingga 21 Maret 2020. Pelaksanaan kegiatan pelatihan pembelajaran daring melibatkan beberapa dosen dari Prodi Pendidikan Vokasional Teknologi Otomotif (PVTO) Universitas Bhinneka PGRI Tulungagung 
dan Jurusan Teknik Mesin Universitas Negeri Surabaya. Dimana masing-masing dosen memiliki keahlian di bidang model pembelajaran daring, pembuatan soal daring, dan asesmen pembelajaran daring. Kegiatan pelatihan pembelajaran daring diselenggarakan di SMK Dharma Bahari Surabaya yang beralamat di Jalan Sikatan Lebar XVI No.1-5, Manukan Wetan, Kec. Tandes, Kota SBY, Jawa Timur 60185.

\section{HASIL, PEMBAHASAN, DAN DAMPAK}

Hasil dari setiap program pelatihan yang telah dilaksanakan dijelaskan sebagai berikut.

\section{A. Pelatihan Penggunaan Platform Google Classroom}

Pelatihan ini bertujuan untuk mengajarkan peserta pelatihan (guru) bagaimana cara memaksimalkan penggunaan google classrom dalam pelaksanaan pembelajaran daring. Topik yang diajarkan seperti bagaimana cara mengunggah bahan ajar, melakukan diskusi, membuat soal pilihan ganda atau essay, dan melakukan penilaian tugas siswa. Pelaksanaan kegiatan yang dilakukan pada tanggal 20 Maret 2020 dapat dilihat pada Gambar 1.
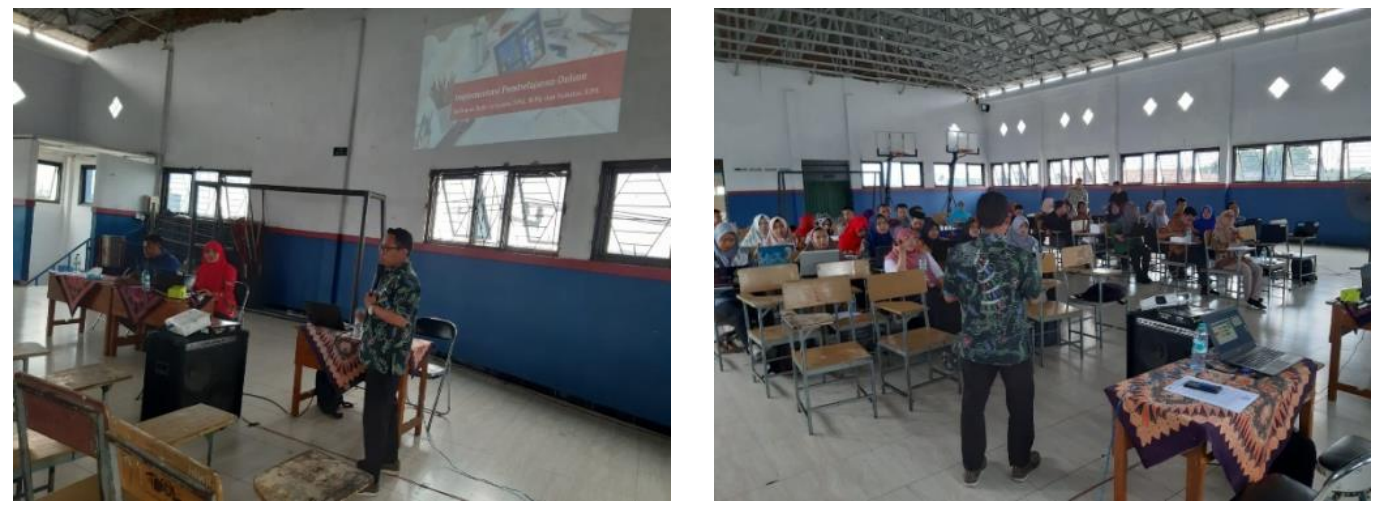

Gambar 1. Pelatihan penggunaan platform google classroom

Peserta yang hadir pada hari pertama pelatihan berjumlah 50 orang. Pada sesi ini peserta pelatihan diajarkan untuk membuat dan menggunggah bahan ajar berupa $e$-book, power point, hingga video tutorial. Video tutorial yang diunggah dapat berupa video yang dibuat secara mandiri ataupun video tutorial yang berasal dari youtube. Sesi ini menjadi menarik bagi para peserta karena penyampaian materi pembelajaran bisa bervariatif. Khusus untuk pembelajaran produktif, selama masa pandemi Covid-19 tentunya tidak akan ada kegiatan praktikum di sekolah sehingga guru pengajar dapat berinovasi dan memaksimalkan pelaksanaan pembelajaran dari dengan cara mengunggah video-video tutorial yang relevan dengan materi pembelajaran (Warju, Ariyanto, Soeryanto, Hidayatullah, \& Nurtanto, 2020).

Setelah siswa mempelajari materi atau video yang telah diunggah maka guru dan siswa dapat melakukan diskusi melalui menu forum. Diskusi tidak hanya dapat dilakukan secara terbatas antara guru dan satu siswa saja, melainkan siswa lain juga dapat bergabung dalam diskusi tersebut. Menu ini wajib diperhatikan oleh guru, karena dapat dijadikan sebagai umpan balik dalam proses pembelajaran. Apabila guru pengajar tidak melakukan diskusi setelah materi diunggah, maka tentunya guru tersebut tidak dapat memastikan apakah materi yang diajarkan dapat dipahami dengan baik oleh siswa atau tidak. Hal ini terjadi karena ada kemungkinan siswa tidak mempelajari materi yang diberikan sehingga proses pembelajaran menjadi tidak maksimal.

Tahap selanjutnya adalah mengajarkan peserta pelatihan bagaimana cara membuat soal baik pilihan ganda maupun essay. Pada google classroom soal essay dapat dilakukan secara terbatas dan bersifat tanya jawab. namun, untuk pembuatan soal dalam jumlah banyak baik 
soal pilihan ganda maupun essay dapat dibuat melalui fasilitas lain dari google yakni google form (Graham \& Borgen, 2018). Membuat soal dari google form sangatlah mudah. Dalam sesi ini, peserta pelatihan diajarkan membuat soal step by step mulai dari bagaimana masuk pada link google form, membuat dokumen baru, melakukan pengaturan form sebagai kuis, memasukkan soal, kunci jawaban, hingga membagikan soal kepada siswa dalam bentuk link (Castro, 2018).

Kemudian setelah tahap ini selesai, dilanjutkan pada sesi bagaimana cara melakukan penilaian di google classroom. Khusus untuk penugasan yang memanfaatkan google form dalam konteks soal pilihan ganda, nilai siswa akan otomatis keluar setelah soal selesai dikerjakan. Sedangkan untuk soal essay, peserta pelatihan dilatih untuk melakukan penilaian secara manual. Selain itu, untuk soal essay yang bersifat tanya jawab dapat langsung dinilai sesuai dengan jawaban masing-masing siswa (Djenno, Insua, \& Pho, 2015). Keuntungan lain yang didapatkan oleh peserta dalam penggunaan google classroom adalah nilai dari beberapa tugas yang telah diberikan kepada siswa dapat didownload secara bersamaan dalam bentuk file excel.

Secara umum sebagian besar peserta yang mengikuti pelatihan terlihat antusias dan memberikan berbagai respon positif. Tidak ditemui kendala yang berarti selama pelatihan berlangung. Hanya saja yang menjadi kurang sempurna adalah sulitnya memberikan pemahaman implementasi google classroom bagi peserta yang berusia diatas 40 tahun. Namun, hal tersebut dapat teratasi berkat inisiatif guru yang berusia relatif lebih mudah untuk membantu memberikan pemahaman dan arahan dalam penggunaan google classroom.

\section{B. Pelatihan Penggunaan Platform Zoom Cloud Meetings}

Pelatihan penggunaan platform zoom cloud meetings diselenggarakan pada hari kedua pelatihan yaitu tanggal 21 Maret 2020. Kegiatan ini bertujuan untuk memberikan variasi teknis pembelajaran daring baik untuk guru maupun siswa, agar sesekali guru juga dapat mengajar secara tatap muka meskipun secara daring. Pelaksanaan kegiatan pelatihan dapat dilihat pada Gambar 2.
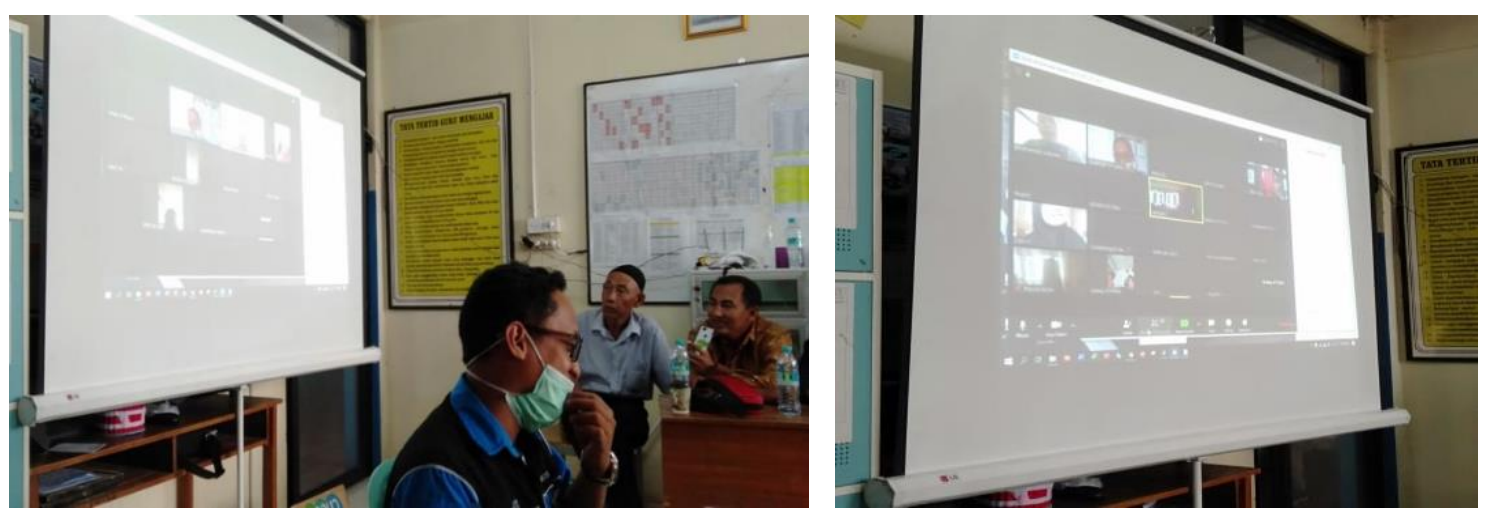

Gambar 2. Pelatihan penggunaan platform zoom cloud meetings

Peserta pelatihan yang hadir pada hari kedua pelatihan berjumlah 50 orang guru. Pada sesi ini peserta diajarkan untuk membuat kelas meeting, membagikan ID dan password meeting, dan melakukan share screen saat mengajar (Zoom Help Center, 2020). Sesi ini menjadi pengalaman baru bagi para peserta karena teknik teleconference atau video call yang sebelumnya diketahui hanyalah terbatas pada aplikasi smartphone seperti whatsapp, facebook, dan instagram dengan jumlah partisipan yang terbatas. Zoom cloud meetings dapat digunakan untuk jumlah partisipan yang telatif lebih besar. Penggunaan zoom dengan 
akun bisnis dapat mengundang hingga 300 partisipan, sedangkan untuk akun Enterprise dapat mengundang hingga 500 peserta dengan durasi meeting hingga 24 jam. Namun untuk akun free hanya dapat mengundang maksimum 100 partisipan dengan durasi video coferencing yang dibatasi hanya selama 40 menit pada setiap meeting (Zoom, 2020).

Secara keseluruhan peserta terlihat antusias mengikuti sesi ini, tidak terdapat kendala saat kegiatan pelatihan berlangsung. Namun, ada beberapa peserta yang menanyakan terkait berapa banyak paket data yang dibutuhkan dalam satu sesi pembelajaran. Kemudian pemateri menjelaskan bahwa jika dibandingkan dengan platform lainnya seperti google meet, penggunaan zoom lebih hemat dari segi paket data dimana dalam satu sesi pembelajaran atau kurang lebih dua jam pembelajaran akan membutuhkan paket data sekita $500 \mathrm{mb}$.

\section{Pelatihan Penggunaan Web Tool Quizizz}

Pelatihan penggunaaan web tool Quizizz diselenggarakan bersamaan pelatihan penggunaan platform zoom cloud meetings. Quizizz sendiri merupakan aplikasi game edukasi yang memungkinkan siswa mengerjakan kuis bersama-sama menggunakan smartphone yang mereka miliki (Yan mei, Yan Ju, \& Adam, 2018). Dari kegiatan ini, para peserta diajarkan untuk membuat soal kuis baik secara mandiri maupun impor dari beberapa soal yang telah tersedia (Zhao, 2019). Selain itu, web tool Quizizz juga menyediakan hasil analisis butir soal sehingga guru dapat lebih akurat menentukan kualitas setiap butir soal (Warju, Ariyanto, Soeryanto, \& Trisna, 2020). Kegiatan pelatihan ini dianggap sangat menarik, karena lebih efektif dan efisien tidak seperti penggunaan google form yang harus memasukkan butir soal satu per satu (Chaiyo \& Nokham, 2017).

Oleh karena itu, beberapa guru mengajak diskusi lebih dalam terkait berbagai kelemahan dan kelebihan dari web tools ini sebagaimana yang ditunjukkan Gambar 3. Kendala yang dihadapi peserta dalam kegiatan pelatihan ini adalah mereka masih mengalami kesulitan dalam memilah hasil pekerjaan siswa apabila dalam satu kuis diperuntukkan untuk lebih dari satu kelas, namun kendala tersebut hanya dirasakan oleh peserta yang berusia rata-rata di atas 45 tahun. Oleh karena itu, perlu diberikan pendampingan secara berkala agar para peserta dapat terbiasa untuk mengoperasikan web tools ini. Sedangkan secara keseluruhan para peserta tidak mengalami kendala yang berarti selama pelatihan seperti tampak pada Gambar 3.
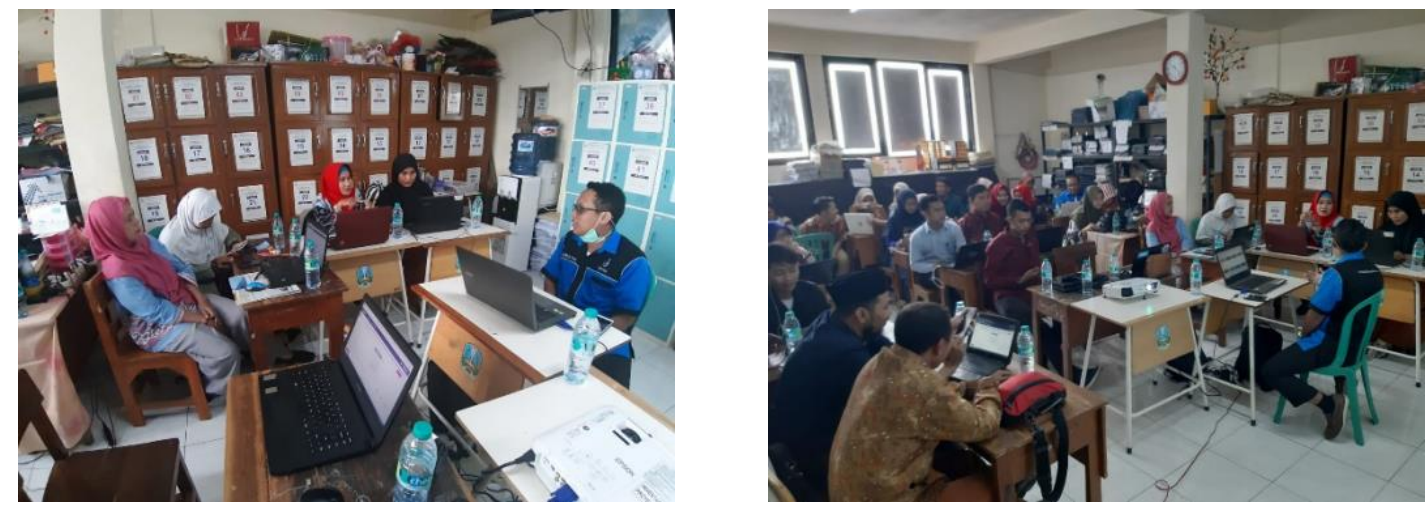

Gambar 3. Pelatihan penggunaaan web tool Quizizz

\section{Dampak Pelatihan Pembelajaran Daring}

Keberhasilan dari kegiatan PKM ini tentunya dapat diukur berdasarkan indikator peningkatan pengetahuan dan keterampilan peserta pelatihan sebagaimana yang ditunjukkan Tabel 1. 
Tabel 1. Indikator pencapaian peserta kegiatan PKM

\begin{tabular}{|c|c|c|c|}
\hline No. & Program Pelatihan & $\begin{array}{l}\text { Jumlah } \\
\text { Peserta }\end{array}$ & Hasil \\
\hline 1. & Google classroom & 50 & $\begin{array}{l}\text { Sebanyak } 34 \% \text { atau } 17 \text { orang guru masuk } \\
\text { kategori "sangat baik", } 50 \% \text { atau } 25 \text { orang guru } \\
\text { masuk kategori "baik", kemudian untuk } \\
\text { kategori "cukup" dan "kurang" masing-masing } \\
\text { sebanyak } 8 \% \text { atau terdiri dari empat orang } \\
\text { guru. }\end{array}$ \\
\hline 2. & Zoom cloud meetings & 50 & $\begin{array}{l}\text { Sebanyak } 40 \% \text { atau } 20 \text { orang guru masuk } \\
\text { kategori "sangat baik", } 52 \% \text { atau } 26 \text { orang guru } \\
\text { masuk kategori "baik", } 2 \% \text { atau } 1 \text { orang guru } \\
\text { masuk kategori "cukup", dan sebanyak } 6 \% \text { atau } \\
3 \text { orang guru masuk kategori "kurang". }\end{array}$ \\
\hline 3. & Web tool Quizizz & 50 & $\begin{array}{l}\text { Sebanyak } 30 \% \text { atau } 15 \text { orang guru masuk } \\
\text { kategori "sangat baik", } 56 \% \text { atau } 28 \text { orang guru } \\
\text { masuk kategori "baik", } 10 \% \text { atau } 5 \text { orang guru } \\
\text { masuk kategori "cukup", dan sebanyak } 4 \% \text { atau } \\
2 \text { orang guru masuk kategori "kurang". }\end{array}$ \\
\hline
\end{tabular}

Adapun apabila data pada Tabel 1 disajikan dalam bentuk diagram pie, maka hasilnya ditunjukkan sebagaimana pada Gambar 4.
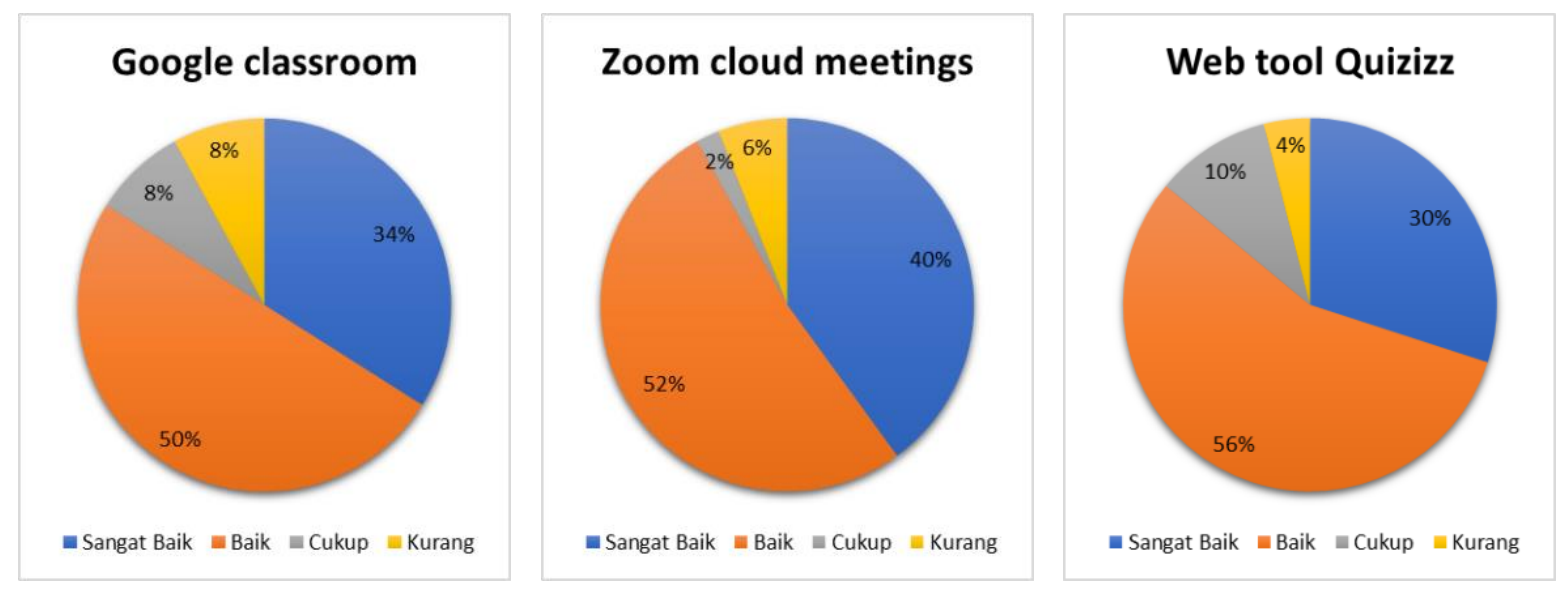

Gambar 4. Diagram pie Indikator pencapaian peserta kegiatan PKM

Berdasarkan data pada Tabel 1 dan Gambar 4, diketahui bahwa secara umum sebagian besar guru merasa kegiatan PKM ini sangat bermanfaat bagi mereka guna mempersiapkan pelaksanaan pembelajaran dari selama masa Pandemi Covid-19. Dampak positif ini diharapkan juga mendapatkan tanggapan positif dari siswa, sehingga proses pembelajaran dapat berjalan dengan maksimal. Lucardie (2014) mengingatkan bahwa kesenangan dan kenikmatan menjadi bagian penting dalam proses pembelajaran. Selain itu, guru wajib mengingat bahwa selama Pandemi Covid-19 siswa melakukan proses pembelajaran secara daring bukan hanya sebatas membuat kelas daring. Artinya selama pembelajaran berlangsung tetap harus ada interaksi antara guru dan siswa, bukan hanya sekedar memberikan tugas dan materi tanpa ada umpan balik. Oleh karena itu, Naz \& Murad (2017) menyarankan agar guru memilih metode dan mengadopsi beberapa strategi pembelajaran yang inovatif untuk memfasilitasi setiap individu 
siswa. Dengan demikian, selama Pandemi Covid-19 siswa tetap mampu meningkatkan kemampuan mereka baik dari ranah kognitif, afektif (Ariyanto, Munoto, \& Muhaji, 2019a), maupun psikomotor (Ariyanto, Munoto, \& Muhaji, 2019b).

\section{SIMPULAN}

Serangkaian kegiatan PKM telah terselenggara dengan baik. Melalui pelatihan ini, secara berurutan sebanyak $34 \%, 50 \%$, dan $8 \%$ peserta masuk kategori "sangat baik", "baik" dan "cukup" dalam mengoperasikan google classroom, sedangkan 8\% lainnya masuk dalam kategori "kurang". Selanjutnya, secara berurutan sebanyak $40 \%, 52 \%$, dan $2 \%$ peserta masuk kategori "sangat baik", "baik" dan "cukup" dalam mengoperasikan zoom cloud meetings, sedangkan 6\% lainnya masuk dalam kategori "kurang". Kemudian, secara berurutan sebanyak $30 \%$, 56\%, dan 10\% peserta masuk kategori "sangat baik", "baik" dan "cukup" dalam mengoperasikan web tool quizizz, sedangkan 4\% lainnya masuk dalam kategori "kurang". Merujuk dari hasil pelatihan tersebut, maka dari segi pengetahuan dan keterampilan para guru atau peserta sudah dapat dikategorikan layak melaksanakan pembelajaran dari selama Pandemi Covid-19. Dengan demikian, meskipun mengajar jarak jauh pembelajaran tetap dapat berjalan dengan maksimal dan siswa juga tetap mampu meningkatkan kemampuan mereka baik dari ranah kognitif, afektif, maupun psikomotor.

\section{UCAPAN TERIMAKASIH}

Terima kasih kepada LPPM Universitas Bhinneka PGRI Tulungagung yang telah memberikan support dalam pelaksanaan pelatihan ini. Terimakasih juga disampaikan kepada SMK Dharma Bahari Surabaya yang telah memberikan kesempatan, ijin, dan dukungan terhadap terlaksananya program pelatihan ini. Selain itu, terimakasih juga kami sampaikan kepada dosen Universitas Negeri Surabaya yang telah memberikan masukan dan saran selama kegiatan pelatihan ini berlangsung.

\section{DAFTAR PUSTAKA}

Ariyanto, S. R., Munoto, M., \& Muhaji, M. (2019a). Development of affective authentic assessment instruments for automotive engineering expertise in vocational school. Jurnal Taman Vokasi, 7(1), 42. https://doi.org/10.30738/jtv.v7i1.4777

Ariyanto, S. R., Munoto, M., \& Muhaji, M. (2019b). Development of Psychomotor Domain Assessment Instrument on Brake System Competence in SMKN 1 Jetis Mojokerto. International Journal for Educational and Vocational Studies, 1(6). https://doi.org/10.29103/ijevs.v1i6.1648

Basilaia, G., \& Kvavadze, D. (2020). Transition to Online Education in Schools during a SARS-CoV-2 Coronavirus (COVID-19) Pandemic in Georgia. Pedagogical Research, 5(4). https://doi.org/10.29333/pr/7937

Castro, S. (2018). Google forms Quizzes and Substitution, Augmentation, Modification, and Redefinition (SAMR) Model Integration. Issues and Trends in Educational Technology, 6(2), 4-14.

Chaiyo, Y., \& Nokham, R. (2017). The effect of Kahoot, Quizizz and Google forms on the student's perception in the classrooms response system. 2017 International Conference on Digital Arts, Media and Technology (ICDAMT), 178-182. https://doi.org/10.1109/ICDAMT.2017.7904957

Dewayani, T. (2020). Bekerja dari Rumah (Work From Home) Dari Sudut Pandang Unit Kepatuhan Internal. Retrieved June 8, 2020, from https://www.djkn.kemenkeu.go.id/artikel/baca/13014/Bekerja-dari-Rumah-Work-

From-Home-Dari-Sudut-Pandang-Unit-Kepatuhan-Internal.html 
Djenno, M., Insua, G. M., \& Pho, A. (2015). From paper to pixels: using Google forms for collaboration and assessment. Library Hi Tech News, 32(4), 9-13. https://doi.org/10.1108/LHTN-12-2014-0105

Graham, M. J., \& Borgen, J. (2018). Google Classroom. In Google Tools Meets Middle School (pp. 23-36). https://doi.org/10.4135/9781506360188.n3

Gubernur Jawa Timur. Peningkatan Kewaspadaan terhadap Corona Virus Disease (Covid-19) di Jawa Timur. , Pub. L. No. 420/1780/101.1/2020 (2020).

Lucardie, D. (2014). The Impact of Fun and Enjoyment on Adult's Learning. Procedia - Social and Behavioral Sciences, 142, 439-446. https://doi.org/10.1016/j.sbspro.2014.07.696

Menteri Pendidikan dan Kebudayaan. Pembelajaran secara Daring dan Bekerja dari Rumah dalam Rangka Pencegahan Penyebaran Corona Virus Disease (COVID- 19). , Pub. L. No. 36962/MPK.A/HK/2020, 1 (2020).

Naz, F., \& Murad, H. S. (2017). Innovative Teaching Has a Positive Impact on the Performance of Diverse Students. SAGE Open, 7(4), 215824401773402. https://doi.org/10.1177/2158244017734022

Pratama, R. (2020). Kantor yang Tak Bisa WFH Harus Sediakan Transportasi untuk Karyawan. Retrieved June 8, 2020, from https://oto.detik.com/berita/d-5043656/kantor-yang-takbisa-wfh-harus-sediakan-transportasi-untuk-karyawan?device=desktop

Warju, Ariyanto, S. R., Soeryanto, Hidayatullah, R. S., \& Nurtanto, M. (2020). Practical Learning Innovation: Real Condition Video-Based Direct Instruction Model in Vocational Education. Journal of Educational Science and Technology, 6(1), 79-91.

Warju, W., Ariyanto, S. R., Soeryanto, S., \& Trisna, R. A. (2020). Analisis Kualitas Butir Soal Tipe Hots pada Kompetensi Sistem Rem di Sekolah Menengah Kejuruan. Jurnal Pendidikan Teknologi Dan Kejuruan, 17(1), 95. https://doi.org/10.23887/jptkundiksha.v17i1.22914

Worldometer. (2020). Coronavirus Updates. Retrieved from https://www.worldometers.info/

Yan mei, S., Yan Ju, S., \& Adam, Z. (2018). Implementing Quizizz as Game Based Learning in the Arabic Classroom. European Journal of Social Science Education and Research, 5(1), 194-198. https://doi.org/10.2478/ejser-2018-0022

Zhao, F. (2019). Using Quizizz to Integrate Fun Multiplayer Activity in the Accounting Classroom. International Journal of Higher Education, 8(1), 37. https://doi.org/10.5430/ijhe.v8n1p37

Zoom. (2020). Plans and Pricing. Retrieved June 8, 2020, from https://zoom.us/pricing

Zoom Help Center. (2020). Meeting and Webinar Passwords. Retrieved June 8, 2020, from https://support.zoom.us/hc/en-us/articles/360033559832-Meeting-and-webinarpasswords 